\title{
DISKURSUS "ILLEGITIMATE SEXUAL ACTIVITY” ANAK BANGSA DALAM PERSPEKTIF TABLOID INDONESIA
}

\author{
Nisa Kurnia I \\ Universitas Airlangga Surabaya \\ Email: looneymochi@gmail.com
}

\begin{abstract}
In Indonesia, sexual activity that has not been legitimized by the state is a reality which is constructed by "masculine-heterosexual" language, which in this context language is defined absolutely by the state. This paper is intended to dismantle the usage of "masculine-heterosexual" language by the Indonesian mass media when defining and putting illegitimate sexual activity in the landscape of the nation's discourse regarding sexuality. Using critical multiculturalism framework, identity theory and constructivist paradigm, this paper will explore discourse articulated by mass media in articles regarding those matters. Using discourse analysis as the method, a corpus of four tabloids (Tabloid Nova No. 1165/XXIII 21-27 Juni 2010, Tabloid Bintang Edisi 997 Tahun XX Minggu Ketiga Juni 2010, Tabloid Wanita Indonesia No. 1069 21-27 Juni 2010, and Tabloid Genie Edisi 50 Tahun VI, 21-27 Juni 2010) are discussed..
\end{abstract}

Keywords: nation identity, illegitimate sexual activity, media studies, discourse analysis, Indonesian's tabloid.

\begin{abstract}
ABSTRAK
Di Indonesia, aktivitas seksual yang belum dilegitimasi oleh negara merupakan salah satu realitas yang dikonstruksi oleh bahasa "maskulin-heteroseksual" yang dalam konteks tersebut merupakan diskursus yang pendefinisiannya mutlak di tangan negara. Tulisan ini hendak membongkar lebih lanjut mengenai penggunaan bahasa "maskulin-heteroseksual" oleh media massa Indonesia dalam mendefinisikan serta meletakkan diskursus illegitimate sexual activity anak bangsa dalam lanskap diskursus seksualitas Indonesia. Menggunakan kerangka pikir critical multiculturalism, teori identitas serta paradigma konstruktivis yang berargumen bahwa media massa merupakan agen konstruksi realitas, tulisan ini hendak mengeksplorasi diskursus yang berusaha diartikulasikan media dalam artikel-artikel yang membahas mengenai hal tersebut. Untuk memetakan diskursus tersebut digunakan metode analisis wacana. Empat tabloid yang digunakan sebagai subjek penelitian, yaitu Tabloid Nova No. 1165/XXIII 21-27 Juni 2010, Tabloid Bintang Edisi 997 Tahun XX Minggu Ketiga Juni 2010, Tabloid Wanita Indonesia No. 1069 21-27 Juni 2010, dan Tabloid Genie Edisi 50 Tahun ke VI, 21-27 Juni 2010.
\end{abstract}

Kata kunci: illegitimate sexual activity, identitas bangsa, media studies, analisis wacana, tabloid Indonesia. 


\section{PENGANTAR}

Di Indonesia, sebuah aktivitas seksual yang belum dilegitimasi oleh negara merupakan salah satu realitas yang dikonstruksi oleh bahasa "maskulin-heteroseksual" (Alimi, 2004: 64). Pengkonstruksian tersebut juga berlaku dalam pendefinisian realitas video mirip Ariel-Luna Maya-Cut Tari, yang utamanya dilakukan oleh media massa. Tulisan ini hendak membongkar lebih lanjut mengenai penggunaan bahasa "maskulinheteroseksual" oleh medua massa Indonesua dalam mendefinisikan serta meletakkan diskursus illegitimate sexual activity anak bangsa dalam lanskap diskursus seksualitas Indonesia. Untuk memetakan diskursus itu, saya menggunakan beberapa tabloid yang membingkai kasus celebrity porn video yang sanggup menyaingi gempita World Cup 2010, di Indonesia (Tabloid Bintang, Edisi 997, 2010: 3).

Kasus illegitimate sexual activity yang melibatkan selebriti ini sebenarnya bukan yang pertama di Indonesia. Namun, yang menyebabkannya mencuat di puncak diskursus adalah para pelakunya yang tengah berada pada puncak popularitas (Tabloid Nova, No.1165, 2010: 3). Seperti yang diungkapkan oleh O'Guinn (2003 dalam Ibrahim, 2007: 133): "Masyarakat abad ke-21 segalanya adalah mengenai selebriti". Apalagi masyarakat Indonesia yang dicekoki tayangan berbumbu selebritas tiap hari dengan intensitas yang tidak bisa dikategorisasikan sebagai sedikit, hingga menganggap kehidupan selebritas menjadi makanan pokok yang tidak mungkin dilewatkan (Haryanto, 2006: 5). Selain acara infotainment di televisi, salah satu media massa garda depan yang menjadikan selebritas sebagai bahan dasarnya adalah tabloid.

Menjadi semakin problematis manakala pasangan selebritis yang tengah disorot tersebut menjadi salah satu pasangan "panutan" bagi para remaja Indonesia (http:/ /www.facebook.com/74677948965/). Selain status sebagai selebritis, kedua individu tersebut memiliki status lain sebagai bagian dari bangsa Indonesia, saya menggunakan istilah anak bangsa. Kasus illegitimate sexual activity di Indonesia yang dilakukan oleh para remaja semakin meningkat tiap tahunnya, ditambah lagi dengan semakin canggihnya teknologi komunikasi yang digunakan untuk mendokumentasikan sekaligus menyebarluaskan aktivitas tersebut. Fenomena ini seolah-olah memecahkan puncak gunung es kasus illegitimate sexual activity yang banyak mencuat pada kondisi realitas Indonesia. Urgensi untuk "meluruskan" diskursus illegitimate sexual activity mulai muncul manakala seksualitas sebagai salah satu bagian dari identitas nasional bangsa mulai dipertanyakan.

Identitas nasional sendiri merupakan salah satu konsep yang problematis di Indonesia. Anggapan bahwa identitas nasional merupakan sesuatu yang given dan karenanya mutlak dilekatkan pada tiap individu, sehingga mengarahkan segala tingkah laku mengikuti standar nilai "nasional" tersebut, menyebabkan berbagai problem yang paradoksal. Sesuai dengan pemikiran Anderson (1983: 5-6) yang mendefinisikan bangsa sebagai "imagined political community-and imagined as inherently limited and soveirgn" sehingga konstruk sebuah kondisi kebangsaan pada dasarnya merupakan diskursus ideologi yang dibayangkan. Menjadi menarik manakala bangsa yang pada dasarnya dibentuk dari beragam latar belakang sosial budaya ditransformasikan menjadi suatu konsep "nasional" yang memiliki nilai seragam.

Inilah yang menyebabkan bangsa menjadi sebuah fenomena modern, sejarah dan kebersamaan yang dibentuk dan dibayangkan, dengan cepat dan secara terus-menerus, oleh banyak orang. Bangsa kemudian menjadi ada melalui sebuah system of signification (Ibid, 40). Karenanya, kebangsaan merupakan sebuah bayangan yang dibangun dan direproduksi terus-menerus melalui sistem pemaknaan serta bahasa yang digunakan oleh individu dalam kehidupan kesehariannya di dalam masyarakat. Menurut Hall, nilai-nilai dasar kebangsaan tersebut dibentuk dari the narrative of nation (Hall, 1992: 293). 
A set of stories, image, landscapes, scenarios, historical events, national symbols and rituals which stand for or represent the shared experience which give meaning to the nation.

Reproduksi nilai-nilai kebangsaan melalui sistem penandaan tersebut turut mengkonstruksi sebuah konsep seksualitas yang dianggap "pantas" oleh negara untuk dilekatkan pada tiap warganya.

Akibat dari reproduksi konsep kebangsaan melalui sistem penandaan tersebut, konstruksi mengenai identitas individu yang menjadi anggota suatu bangsa pada dasarnya akan selalu berubah bergantung pada penguasa sistem penandaan tersebut. Seperti yang diungkapkan oleh Foucoult (1968: 127):

But we know very well that, in its distribution, in what it permits and what it prevents, it follows the lines laid down by social differences, conflicts and struggles. Every educational system is a political means of maintaining or modifying the appropriation of discourses, with the knowledge and power they bring with them.

sehingga diskursus ke"bangsaan" menjadi terartikulasikan dalam penggunaan bahasa sehari-hari dalam membingkai sebuah realita. Realita yang bersinggungan langsung dengan lokus identitas, seperti etnisitas, agama, kelas, wilayah serta gender dan seksualitas menjadi bergantung pada penggunaan bahasa tersebut untuk mendefinisikannya. Termasuk dalam kasus video "mirip" artis tersebut. Seperti yang disampaikan oleh Foucault, heteroseksualitas bukan hanya didirikan di atas naturalisasi dan pelipatgandaan tingkah laku seksual yang prokreatif, melainkan juga pada patologisasi, abnormalisasi setiap bentuk praktik seksual yang nonprokreatif. Sehingga bagi setiap aktivitas seksual yang dinilai nonprokreatif, yang dalam konteks paper ini adalah illegitimate sexual activity didefinisikan sebagai sesuatu yang patologis.

Pemerintah Indonesia, khusunya pada masa Orde Baru yang mengusung konsep negara integralistik (Suryakusuma, 1991 dalam Hadiz, 2004: 355) menganalogikan Negara dengan konsep azas kekeluargaan. Dengan kata lain, negara sebagai keluarga yang memiliki dasaran UUD 1945 sehingga menggunakan Patrimonialisme (suatu ideolog yang menggabungkan laki-laki dan perempuan dalam suatu konteks yang integral (rumah tangga) sebagai landasan struktur pelapisan sosial di Indonesia, dengan Presiden sebagai Bapak Utama. Terdapat ciri hubungan kawula-gusti yang kuat dalam budaya politik Jawa, yang ditandai oleh hormat pada kekuasaan dan otoritas, yang sejalan dengan hirarkhi. "Kawula" digunakan sebagai kata ganti orang dengan kedudukan yang lebih rendah, sementara "Gusti" digunakan untuk penguasa atau yang lebih tinggi. Salah satu slogan yang diusung Orde Baru adalah proyek "Pembangunan Nasional" yang membutuhkan pemerintah yang kuat, stabil dan berwibawa, yang didukung oleh aparat negara yang "sempurna", salah satunya adalah keluarga sebagai bagian integralistik dari negara.

Rumah tangga adalah merupakan unit masyarakat yang terkecil dari sebuah negara ... Negara hanya akan kuat apabila terhimpun dari rumah tangga-rumah tangga yang kuat. Negara yang adil hanya akan terwujud dari susunan rumah tangga yang adil.

(Rekso Soedirjo, 1990:17; Hadiz, 2004:360)

Oleh karena itu, menegakkan sebuah rumah tangga berarti ikut berpartisipasi menegakkan suatu Dasar Negara.

Pandangan konstruksi identitas nasional bangsa yang didengungkan pada masa Orde Baru ternyata masih direproduksi pada masa reformasi. Sesuai dengan pandangan heteronormativitas yang lebih memihak pada politik maskulin, negara sebagai manifestasi puncak dari konsep "keluarga" tersebut memiliki kewajiban untuk "menjaga" anak-anak bangsa mereka menggunakan ideological state apparatus yang salah satunya diartikulasikan oleh media massa. Untuk mempertahankan diskursus kebangsaan yang sesuai dengan identitas nasional maka seluruh proses yang menggunakan sistem penandaan dikonstruk sedemikan rupa sehingga berjalan sejalan dengan the narrative of nation. 
Saya menggunakan empat tabloid untuk membongkar konstelasi diskursus illegitimate sexual activity di Indonesia yang direpresentasikan oleh kasus celebrity porn video tersebut. Pemilihan tabloid sebagai objek pengamatan bukannya tanpa implikasi, mengingat tabloid merupakan suatu media yang pada dasarnya memiliki segmentasi kelas bawah, salah satu indikatornya adalah harganya yang berada pada kisaran 60007000 rupiah serta bahan dasarnya yang dari kertas koran, bukan glossy (McLaughlin, 2000: 5). Penggunaan kata glossy adalah salah satu indikator dari media massa yang ditujukan untuk kelas menengah. Sehingga, asumsi dasar yang digunakan bahwa menurut kelas tersebut, isu illegitimate sexual activity masih menjadi diskursus seksualitas yang memiliki tingkat urgensi cukup tinggi mengingat peletakannya sebagai isu utama di semua tabloid yang tengah beredar pada masa ini.

Menggunakan pendekatan 'critical multiculturalism', penulis hendak membedah konstelasi wacana multikulturalisme dan seksualitas yang berusaha diartikulasikan melalui artikel-artikel dalam keempat tabloid yang digunakan sebagai sampel. Untuk memaparkan realitas seksualitas dan multikulturalisme tersebut, penulis akan memperhatikan beberapa elemen. Karena sebuah pendekatan critical multiculturalism memiliki perspektif yang cukup luas, sehingga penilaian mengenai realitas multikultur harus disarikan dari berbagai elemen pembentuk diskursus. Seperti yang diungkapkan oleh Kellner (Ibid):

A critical multicultural perspective takes seriously the conjunction of class, race, ethnicity, gender, sexual preference, and other determinants of identity as important constituents of culture which should be carefully scrutinized and analyzed in order to detect sexism, racism, classism, homophobia, and other tendencies that promote domination and oppression.

Untuk itu, saya akan memaparkan pemosisian pelaku dan korban, serta peran serta saksi ahli yang memiliki legitimasi pengetahuan untuk menjustifikasi kebenaran vi- deo tersebut, dan yang terakhir posisi negara sebagai puncak legitimasi seksualitas, untuk menganalisis bagaimana diskursus seksualitas dalam perspektif critical multiculturalism dalam artikel-artikel yang ditampilkan oleh tabloid-tabloid tersebut. Dengan pendekatan ini diharapkan hasil analisis yang lebih komprehensif. Pertanyaan utama yang akan dijawab melalui tulisan ini adalah bagaimanakah artikel-artikel dalam tabloid Indonesia mengartikulasikan diskursus seksualitas anak bangsa, utamanya illegitimate sexual activity, melalui sistem penandaan, menggunakan perspektif multikulturalisme kritis.

\section{Identitas dan Tabloid sebagai Agen Konstruksi Realitas}

Pendefinisian mengenai gender dan seksualitas sebagai salah satu lokus identitas individu sendiri selalu mengalami perdebatan. Menurut Judith Butler (1999: 25), gender itu bersifat performatif, hal ini menyatakan secara tidak langsung bahwa identitas gender seseorang dihasilkan melalui penampilan (performance) dan permainan peran (role-playing). Pengulangan memainkan peran penting dalam proses ini, karena dengan menampilkan tindakan-tindakan tertentu secara berulang individu memperoleh sebuah identitas koheren yang nyata. Selanjutnya pengulangan didikte oleh seperangkat tata nilai yang berupa ekspektasi oleh budaya tertentu terhadap anggotanya, oleh ideologi dominan dan cara-cara mengatur perilaku seksual.

'Performa gender', menurut Butler, bergantung pada praktik-praktik pengulangan rezim-rezim seksual yang bersifat mengendalikan. Sebuah peran gender, oleh karenanya, tidak bersifat alami maupun opsional. Pada kenyataannya peran gender terkonstruksi oleh pelbagai wacana kultural, dan khususnya oleh bahasa. Melalui kegiatan mendisiplinkan tubuh dan menyesuaikannya dengan performa gender yang dituntut oleh lingkungan sosiokultural akan memungkinkan terjadinya, apa yang disebut Foucault sebagai "ledakan diskursus sek- 
sualitas". Menurut Foucault (1988 dalam Alimi, 2004: 76), seksualitas merupakan ruang yang paling dalam tempat terkuburnya kebenaran tentang diri, sebagai inti esensial yang mendasari kesadaran rasional yang mungkin muncul dan membentuk identitas.

Sebagai respons atas pemikiran tersebut, Yuval Davis (1977 dalam Alimi, 2004: 76) mengungkapkan bahwa seksualitas memainkan peranan penting dalam reproduksi bangsa secara sosial (the social production of nation) atau disebut juga dengan kulturnation dan reproduksi bangsa secara biologis (the biological production of nation) atau disebut juga sebagai volknation. Melalui kulturnation, relasi gender dan seksual digunakan sebagai pusat pembentukan identitas nasional. Sementara volknation, digunakan untuk mengamankan integritas bangsa, batas dan fungsi tubuh diatur ketat. Batas-batas ditentukan, dijaga, dan para penyimpang seksualnya diidentifikasi melalui teknikteknik baru pengetahuan, dan dieksklusi melalui teknik "kuasa" sehingga bangsa dapat mengonsolidasikan pemahaman komunitas yang lebih kuat. Sejalan dengan pemikiran tersebut, proses pendefinisian sebuah praktik seksual menjadikan "the narrative of nation" sebagai acuan utama.

Tabloid merupakan sebuah produk budaya yang dibuat oleh suatu institusi media massa yang notabene merupakan bagian dari masyarakat sosial itu sendiri. Menurut McQuail (2000: 61) tabloid (media massa), budaya (culture), dan masyarakat (society) adalah tiga hal yang tidak dapat dipisahkan. Tabloid merupakan suatu produk budaya yang memanifestasikan gagasangagasan suatu masyarakat mengenai suatu realita (objek). Objek tersebut tidak sertamerta ditampilkan sebagaimana adanya, melainkan mengalami sebuah presentasi ulang yang merupakan hasil konstruksi pihak yang memroduksi teks tersebut.

Bahasa populer untuk realitas kedua ini adalah representasi. Menurut Stuart Hall (2002: 15) yang dimaksud dengan representasi adalah suatu aktivitas komunikasi yang menggunakan bahasa yang memiliki makna tertentu yang didefinisikan secara sosio- kultural untuk menggambarkan, mewakilkan, atau mempresentasikan ulang suatu objek (atau realita). Sehingga proses representasi pada dasarnya adalah proses mengkonstruksi ulang realita melalui bahasa yang memiliki pemaknaan konsensual.

Bentuk representasi realitas ideal ini pada akhirnya menjadi suatu praktik diskursif yang dijalankan oleh sistem masyarakat untuk melanggengkan status quo mereka. Dapat dikatakan bahwa melalui tabloid, institusi yang memroduksinya juga melakukan penetrasi ideologi terhadap para pembacanya dalam bentuk representasi realitas tersebut. Sehingga sedikit banyak dapat dikatakan bahwa praktik diskursif yang berlangsung dalam sebuah tabloid, sebenarnya juga tengah berlangsung dalam realitas sosial masyarakat itu sendiri. Praktik-praktik diskursif tersebut pada akhirnya memproduksi, mereproduksi, atau bahkan melanggengkan wacana yang mendukung suatu kekuasaan dominan yang menghasilkan "common sense" atau "taken for granted" bagi publik yang mengonsumsinya.

Dapat dikatakan bahwa tabloid menampilkan suatu realitas simbolis yang merupakan representasi dari realitas faktual yang terjadi di lingkungan sosial. Realitas simbolis ini diproduksi melalui interaksi simbolis yang dibentuk oleh bahasa dan konvensi atau pemaknaan bersama (Fiske, 1996: 5356). hingga penggunaan bahasa yang digunakan untuk merepresentasikan realitas tersebut menjadi bias dan tidak bebas nilai. Oleh karena itu, dalam setiap pemilihan bahasa yang hendak digunakan selalu ada nilai-nilai yang melekat dalam penggunaan bahasa tersebut. Penggunaan bahasa di sini tidak hanya terbatas pada kata-kata, melainkan juga pada atribut, gestur, serta bahasabahasa tabloid seperti angle, plot, ataupun layout (McLaughlin (2000: 8). Jadi, pada dasarnya realitas simbolis yang ada pada tabloid memberikan penawaran nilai-nilai tertentu kepada pembacanya mengenai kondisi masyarakat yang ideal.

Penelitian ini menggunakan pendekatan kualitatif berbasis paradigma kritis, menggunakan metode Discourse Analysis. Pende- 
katan kualitatif artinya penelitian ini adalah sebuah Grounded Research yang berangkat dari fenomena sosial yaitu konstruksi sosial mengenai konsep "illegitimate sexual activity" yang direpresentasikan dalam tabloid Indonesia. Fenomena ini dianalisis menggunakan paradigma kritis yang dasar filosofinya adalah realitas sosial yang ada sekarang ini adalah sebuah realita yang timpang dikarenakan adanya dominasi dari kelompok tertentu yang melanggengkan kekuasaannya melalui wacana dalam kehidupan sehari-hari (everydaylife discourse).

Sehingga Discourse Analysis dalam konteks penelitian ini digunakan sebagai instrumen dalam upaya peneliti untuk memahami, mengungkap, membongkar, dan akhirnya melawan struktur kekuasaan yang terbentuk dari wacana-wacana yang dilanggengkan oleh kultur mengenai diskursus "illegitimate sexual activity" anak bangsa dalam tabloid Indonesia. Keempat tabloid yang saya gunakan adalah, Tabloid Nova No. 1165/ XXIII 21-27 Juni 2010, Tabloid Bintang Edisi 997 Tahun XX Minggu Ketiga Juni 2010, Tabloid Wanita Indonesia No. 1069 21-27 Juni 2010, dan yang terakhir adalah Tabloid Genie Edisi 50 Tahun ke VI, 21-27 Juni 2010.

\section{PEMBAHASAN \\ Siapa Pelaku, Siapa Korban?}

Salah satu perdebatan yang timbul dari munculnya kasus ini adalah mengenai posisi pelaku dan korban. Dari judul yang terpampang di sampul depan tabloid-tabloid tersebut sudah tampak penggunaan sistem penandaan yang mengartikulasikan pandangan mereka mengenai posisi korban dan pelaku. Judul yang diusung oleh Tabloid Nova yaitu "Main Api Terbakar Sendiri" jelas memosisikan para anak bangsa yang terlibat sebagai pemain video tersebut sebagai pelaku yang sudah selayaknya mendapat hukuman. Penggunaan metafora main api terbakar sendiri, memiliki makna denotatif bahwa para pemeran dalam video tersebut telah melewati batas-batas norma kesusilaan di Indonesia sehingga mereka "wajar" memperoleh akibatnya.

Sudut pandang lain ditampilkan oleh Tabloid Genie yang memilih judul utama "Video itu Asli; Ariel hanya Memanfaatkan Luna". Posisi korban disandangkan pada Luna sebagai objek pasif dari pelaku Ariel sebagai subjek aktif. Posisi ini ditentukan oleh penggunaan kata "memanfaatkan". Bahasa maskulin ini juga melegitimasi bahwa perbuatan mereka tidak prokreatif karena menimbulkan kerugian bagi pihak lain, yang dalam hal ini adalah Luna. Sementara Tabloid Bintang yang menggunakan judul utama "Imej dan Karier Berantakan, ArielLuna Tetap Tak terpisahkan", menawarkan sudut pandang lain bahwa illegitimate sexual activity akan memberikan konsekuensi buruk bagi kehidupan individu yang melakukannya. Walaupun tabloid ini tidak menawarkan posisi pelaku atau korban, namun secara gambling tabloid ini mengusung diskursus dominan bahwa illegitimate sexual activity adalah kesalahan yang harus mendapat hukuman.

Tabloid Bintang merupakan salah satu tabloid yang memaparkan perdebatan posisi pelaku-korban dari berbagai perspektif. Tidak hanya menghakimi anak bangsa pelaku illegitimate sexual activity secara sepihak, Bintang mencoba untuk memberikan wadah bagi para "pelaku" adegan-adegan tersebut untuk membeberkan perasaan mereka.

Dalam sesi wawancara itu, berkali-kali LunaAriel menekankan mereka korban dari orangorang yang ingin melihat karier mereka hancur (Tabloid Bintang, Edisi 997, 2010: 3).

Pada dasarnya, para partisipan illegitimate sexual activity merasa menjadi korban dengan beredarnya video tersebut, dan mereka menempatkan para pengganda video tersebut sebagai pelaku. Senada dengan bintang, Tabloid Genie juga menyuarakan hal serupa, bahwa tidak ada ruginya meminta pihak yang bersangkutan secara langsung dalam memberikan pandangan mereka terhadap masalah tersebut. Walaupun sebagai 
implikasi logis dari beredarnya dokumentasi tersebut menimbulkan efek domino bagi korban-korban lainnya.

Menggunakan angle yang berbeda, Bintang juga memaparkan pendapat individuindividu seperti Ade Armando dan Tifatul Sembiring yang dianggap memiliki legitimasi akan kebenaran mengenai siapa yang menjadi pelaku dan siapa yang menjadi korban.

Masalah utamanya, penyebaran video porno yang tidak terbendung dengan cara yang jahat, secara sengaja, dan sistematis. Jadi kalau ada yang menyebut Luna dan Ariel korban, harusnya kita melihat lebih luas lagi. Korban sebenarnya masyarakat luas. Bukan mereka" (Ibid, 2).

Masalah video itu cukup menguras perhatian publik. Kalau itu benar mereka, bukan saya saja yang kecewa. Mereka ini idola puluhan juta jiwa anak muda Indonesia....Menurut saya, korban sebenarnya anak-anak. Mereka bisa saja meniru (Ibid, 4).

Tabloid Bintang mengutip pernyataan Ade Armando, seorang pengamat media yang telah dikenal luas oleh masyarakat Indonesia. Ade Armando yang dianggap memiliki kredibilitas untuk menanggapi kasus ini menyatakan bahwa korban yang lebih luas adalah masyarakat Indonesia, dan para pelaku video tidak sepantasnya memosisikan diri mereka sebagai korban. Pernyataan ini ditekankan kembali oleh tabloid Bintang menggunakan pernyataan Tifatul Sembiring, Menkominfo Kabinet Indonesia Bersatu II. Korban sebenarnya adalah anakanak, yang ditekankan oleh Tifatul sebagai penggemar Ariel dan Luna, yang bias saja meniru perbuatan mereka.

Seperti yang telah dipaparkan sebelumnya, kondisi sebuah negara yang sistemik pada akhirnya menempatkan sebuah diskursus seksualitas pada jalinan diskursus identitas nasional pada sebuah masyarakat. Sehingga, tidak heran jika bagi media massa, selalu ada berbagai macam versi yang merujuk pada pelaku maupun korban dari kasus tersebut. Namun, dengan melihat paparan dari tabloid Bintang, bisa dilihat kecenderungan angle yang lebih memihak pada diskursus identitas nasional yang menempat- kan anak bangsa yang berpartisipasi dalam video sebagai pelaku dan masyarakat luas sebagai korban.

Jika Bintang berusaha menampilkan dari berbagai perspektif, lain halnya dengan Nova yang cenderung mengambil posisi ofensif dalam kasus ini.

Mereka ini kan, sengaja merekam aktivitas seksual mereka. Video itu tidak akan pernah ada jika mereka tidak merekamnya. Bagaimana mungkin mereka hanya sebagai korban? (Tabloid Nova, No.1165, 2010: 8).

Bagi Tabloid Nova, Ariel, Luna dan Cut Tari tidak mungkin diposisikan sebagai korban mengingat merekalah yang memroduksi dokumentasi illegitimate sexual activity tersebut. Namun yang menjadi polemik, dari ke semua taboid tersebut tidak ada yang menyuarakan secara gamblang siapa yang bisa divonis menjadi pelaku. Meskipun hingga artikel tersebut dipublikasikan Ariel sudah ditetapkan menjadi tersangka dan menjadi tahanan tetap, media massa juga belum merujuk pada pelaku utama yang patut dihukum.

Menurut saya, setidaknya para tabloid itu masih mengusung asas praduga tak bersalah. Walaupun di setiap artikel memiliki nada-nada yang memihak, namun belum ada yang mengutuk atau menjustifikasi salah satu individu yang ditetapkan sebagai pelaku sebelum hukum menyatakan demikian. Sehingga, dari perdebatan ini bisa disimpulkan jika media massa berada pada posisi mediator dalam kasus ini, mereka menyiarkan, menambahi sedikit bumbu agar sedap, namun tidak langsung menjustifikasi.

Namun, media massa tidak sepenuhnya lepas tangan dalam mendengungkan pemberitaan tersebut sehingga menjadi penting bagi publik yang mengonsumsinya. Tabloid Bintang menyadari benar kalau diri mereka turut andil dalam kasus ini, sebagai "pelaku" penyebaran: Kasus ini jelas tidak bisa disepelekan. Apalagi media memberitakan dengan gencar. Masyarakat disuguhi gambar, tontonan yang mendorong rasa ingin tahu". Ketiga tabloid lain, juga merasa bahwa pem- 
beritaan yang dilakukan oleh media massa semakin mendorong rasa ingin tahu masyarakat, utamanya anak-anak penggemar ketiga selebritas tersebut, sehingga memosisikan media massa sebagai salah satu pelaku penyebaran video tersebut. Hal ini juga diafirmasi oleh Tifatul Sembiring yang merasa media massa terlalu sering menampilkan peristiwa tersebut.

Di sisi lain, dalam memosisikan pelaku dan korban dalam ulasan rubriknya, para tabloid ini memiliki kecenderungan yang seragam. Pertama, mereka sepakat meletakkan masyarakat, utamanya anak-anak, sebagai korban dari peristiwa ini. Kedua, semua sepakat bahwa para pelaku illegitimate sexual activity memiliki andil dalam peristiwa tersebut, walaupun posisinya tidak dapat dikatakan sebagai pelaku atau korban. Yang terakhir, seluruh tabloid menyepakati bahwa illegitimate sexual activity adalah perbuatan yang salah. Jika melakukannya maka akan menerima konsekuensi negatif baik itu formal (dituntut secara hukum) maupun informal (dikucilkan, disalahkan dan dicela oleh publik) karena menyalahi norma kesusilaan yang dikonstruk oleh identitas nasional sebagai anak bangsa.

\section{Posisi "Saksi Ahli"}

Di sini, istilah saksi penulis gunakan untuk merujuk pada individidu yang dianggap tabloid memiliki kredibilitas untuk membahas peristiwa ini dari sudut pandang kompetensi masing-masing. Menurut Stephen Littlejohn (2000: 237-238), Foucault menyatakan bahwa setiap periode peradaban manusia memiliki perbedaan sudut pandang dalam melihat dunia, yang ia sebut sebagai struktur konseptual (conceptual structure), yang menentukan pendefinisian kebenaran melalui pengetahuan yang dianggap sudah seharusnya (the nature of knowledge) pada masa itu. Sehingga, setiap pengetahuan pasti memiliki karakteristik tertentu sesuai dengan periode peradaban di mana ia digunakan. Foucault menyebutnya sebagai epistemé atau formasi diskursif (discursive formation).
Maka dari itu, untuk melanggengkan kekuasan melalui formasi wacana yang beredar, maka harus ada kontrol terhadap wacana itu sendiri. Foucault menyebutnya sebagai 'rarefaction of the speaking subjects' dengan tiga cara utama, yaitu memberikan suatu kualifikasi tertentu agar individu dapat diakui sebagai subjek yang berbicara, terkait dengan dimensi ruang dan waktu di mana wacana tersebut disampaikan. Yang kedua dengan membatasi kelompok tertentu yang dapat diakui sebagai subjek, serta yang terakhir adalah legitimasi secara formal terhadap subjek yang berbicara, dan legitimiasi tersebut hanya bisa didapatkan dengan satu cara, pendidikan formal.

Individu yang memiliki legitimasi sebagai subjek yang berbicara pada akhirnya memiliki akses terhadap peredaran wacana. Seperti yang diungkapkan oleh Foucault (1968: 127) berikut ini:

But we know very well that, in its distribution, in what it permits and what it prevents, it follows the lines laid down by social differences, conflicts and struggles. Every educational system is a political means of maintaining or modifying the appropriation of discourses, with the knowledge and power they bring with them.

Dapat diambil kesimpulan bahwa pengetahuan (knowledge) adalah gerbang untuk meraih kekuasaan (power) dalam merumuskan dan melanggengkan ideologi dominan bagi suatu tatanan masyarakat melalui proses komunikasi yang memroduksi wacana.

Itulah yang tergambar jelas dalam pendefinisian kebenaran dalam kasus illegitimate sexual activity yang divideokan tersebut. Para ahli telematika seperti Roy Suryo dan Abimanyu dijadikan garda depan dalam pembuktikan kebenaran sekaligus menjustifikasi secara moral para pelaku dan aktivitas yang mereka lakukan. Para psikolog berlomba-lomba membuat pernyataan yang melegitimasi kebenaran versi mereka mengenai realita illegitimate sexual activity yang dilakukan oleh selebriti. Para pengacara, juga dengan standar kebenarannya secara judicial, turut memosisikan illegitimate sexual activity dalam diskursus seksualitas nasional. 
Setelah lihat video tersebut dari bukti yang dipegang polisi, saat itu pula saya merasa Luna berbohong menyatakan video itu rekayasa. Tadinya saya kira Luna jujur kesaya, menyatakan video itu rekayasa. Setelah melihat video itu, saya nyatakan, video itu asli $100 \%$. Tidak mungkin rekayasa (Tablodi Nova, No.1165, 2010: 4).

Menjadi problematis, manakala saksi ahli yang dijadikan pelegitimasi kebenaran dalam kasus tersebut tidak hanya sekedar memberikan pendapat objektif mengenai asli tidaknya video yang beredar. Namun mereka turut menjustifikasi moralitas para pesertanya serta memberikan alternatif hukuman bagi mereka. Seperti yang dilakukan oleh Roy Suryo, yang merasa kuatir jika peredaran video ini bisa merusak moral bangsa.

Selain melihat dari sudut pandang moralitas, berbagai saksi ahli dihadirkan untuk mengulas peristiwa ini dari berbagai sudut pandang. Seperti yang dilakukan oleh tabloid Bintang yang menggunakan Effendi Ghazali, seorang pengamat media, sebagai narasumber utamanya.

Yang bisa menjerat Ariel dan Luna adalah kenyataan lain bahwa mereka melakukan hubungan seks sebelum menikah. Mereka bisa terjerat undang-undang perzinahan (Tabloid Bintang, Edisi 997, 2010: 2).

Ghazali memberikan pernyataan bahwa, illegitimate sexual activity yang didokumentasi dan disebarluaskan pada dasarnya bukan faktor terpenting. Yang lebih penting adalah aktivitas seksual di luar konsep pernikahan yang dilegitimasi oleh Negara. Pelanggaran, pada dasarnya dilakukan oleh para anak bangsa ini karena aktivitas seksual diatur sepenuhnya oleh negara. Sebagai pengamat media Ghazali mengambil posisi komentator yang menyatakan bahwa hukum berpihak pada individu yang mematuhi hukum Negara dalam melakukan aktivitas seksual.

Para tabloid ini juga menyoroti perilaku para pemain video ini dari sudut pandang psikologis. Sudut pandang psikologis yang digunakan pun diambil dari dua sisi. Sisi pertama adalah psikologi popular dan sisi kedua adalah sudut pandang psikologi agama.

Ariel itu superstar, naughty boy. Di dalam dunia pergaulan, naughty boy hard to resist. Saya enggak akan bilang dia psycho ... Wahai Ariel, Luna, Cut Tari, bangsa Indonesia itu bangsa yang permisif dan pardonis, mudah memaafkan serta nrima. Kalau Anda berulang-ulang tidak mengaku, orang bisa kesal (Tabloid Nova, No.1165, 2010: 7).

Mengacu pada kasus video porno yang pelakunya mirip Ariel dan Luna, Psikiater Dadang Hawari menduga si pelaku pria menderita 3 penyimpangan seks sekaligus, narsisme, ekshibisionist dan satirisme ... "Sekarang begini, pasangan suami istri melakukan seksual memang hal yang sah di agama. Masalahnya timbul karena dilakukan bukan dengan pasangan. Lalu semakin menjadi masalah lagi, ketika video tersebut bocor ke publik" (Tabloid Wanita Indonesia, No.1069, 2010: 31).

Narasumber yang dipilih oleh Tabloid Nova, Prasantyo, mewakili sudut pandang psikologi populer menyatakan bahwa apa yang dilakukan oleh Ariel bukanlah hal yang patologis di dalam lingkungan sosial. Yang menjadikan seorang Ariel menjadi berganta-ganti pasangan dalam melakukan illegitimate sexual activity adalah kepribadiannya yang sulit ditolak oleh para selebriti perempuan Indonesia.

Berbeda lagi sudut pandang yang digunakan oleh Dadang Hawari. Menurut Dadang, apa yang dilakukan oleh para pemain video tersebut, utamanya adalah pemeran pria, merupakan suatu hal yang patologis. Dadang bahkan menjustifikasi pemain pria dalam video tersebut sebagai individu yang menderita penyimpangan seksual. Dadang bahkan tidak ragu untuk menyebut Ariel sebagai "penderita" penyimpangan seksual dan menyampaikan bahwa pokok permasalahan dari peristiwa itu adalah terjadinya illegitimate sexual activity. Masalah tersebut menjadi makin besar manakala publik telah mencium permasalahan tersebut.

Sementara itu, tabloid Genie mengambil angle berbeda dengan membahas masalah 
ini dari sudut pandang agama. Menggunakan Ketua MUI, Amidhan, sebagai narasumber utama.

Dari sisi agama sudah jelas itu perbuatan dilarang. Dosa besar. Tidak bisa ditolerir. Tapi kalau agama kan hukumannya di akhirat, ya... Karena ini kejahatan sosial yang sangat merusak masyarakat. Video itu kan bisa diakses jutaan orang dan akan merusak moral jutaan orang (Tabloid Genie, Edisi 50, 2010: 5).

Setiap ahli dari masing-masing bidang yang dianggap memiliki legitimasi untuk menjustifikasi kasus tersebut turut memberikan perspektifnya mengenai kebenaran dalam konteks diskursus illegitimate sexual activity yang didokumentasikan tersebut. Apakah mengategorisasikan mereka sebagai pembohong, pezinah atau bahkan memiliki kelainan seksual.

Para tabloid Indonesia mengambil anglenya masing-masing dalam mendefinisikan para pemain dari dokumentasi seksual tersebut. Kesepakatan yang tibul dari pemberitaan tersebut adalah para pemain dianggap melanggar prinsip good sex heteronormativitas dari perspektif manapun. Mulai dari perspektif agama, sosial hingga psikologikal. Atau dengan kata lain, tabloid masih mengikuti narasi besar heteronormatif yang meletakkan illegitimate sexual activity yang didokumentasikan sebagai diskursus seksualitas yang menyimpang dan harus dibenahi. Hal ini senada dengan konstruksi identitas nasional bangsa yang diartikulasikan menggunakan bahasa maskulin-heteroseksual yang meletakkan para anak bangsa sebagai pihak yang melakukan pengrusakan identitas bangsa.

\section{Negara sebagai Puncak Legitimasi Seksualitas}

Diskursus negara integralistik yang diusung oleh Orde Baru untuk mengonstruksi identitas nasional ternyata masih direproduksi serta dijadikan kerangka pikir utama negara dalam mengonstruksi kehidupan masyarakat Indonesia, sehingga pihak-pihak yang memiliki hubungan langsung de- ngan pemerintah, yang menjadi "bapak" negara, merasa memiliki urgensi untuk turut campur mengonstruksi pemikiran publik mengenai kasus ini. Tidak hanya Menteri Komunikasi dan Informatika yang memiliki keterkaitan dengan peredaran informasi, baik itu cetak maupun elektronik, mulai dari Presiden hingga Ketua RT merasa perlu untuk berkomentar dan meluruskan pemikiran bangsa dalam memandang dan mencerna kasus ini. Atau dengan kata lain untuk memberikan arahan bagi "anakanaknya".

Ketua MUI yang berbicara dari sudut pandang agama bahkan menyatakan perlunya para anak bangsa yang menjadi pelaku untuk segera "diamankan" karena mereka akan menimbulkan dampak negatif bagi masyarakat. "Pengamanan" itu juga bukan bentuk pengamanan sembarangan, Ketua MUI mendesak kepolisian sebagai Repressive State Apparatus untuk bertindak cepat dalam memberikan hukuman bagi para pemain video tersebut.

Pernyataan dia (Ariel, red) yang menyatakan korban berarti ia mengakui itu (video) ada. Mengakui itu benar. Dan para ahli menyatakan video ini bukan rekayasa. Menurut saya, polisi jangan lamban seperti sekarang ... Bagi kita, polisi seharusnya melihat dampak yang besar di masyarakat. Polisi harus lebih tegas dan tidak hanya mengatakan mereka sebagai korban (Ibid, 5).

Kepolisian sebagai perpanjangan tangan dari pemerintah dianggap sebagai pihak yang paling memiliki legitimasi untuk mengkonstruksi pandangan masyarakat mengenai kasus ini yang bisa dikategorikan sebagai "kejahatan". Para pelaku juga tidak memiliki hak untuk mendeklarasikan diri mereka sebagai korban mengingat dampak yang terlalu besar yang mereka timbulkan pada masyarakat.

Tidak hanya Ketua MUI yang menganggap polisi sebagai legitimasi puncak dalam menindak para pelaku video tersebut, Ketua RT di kediaman Luna Maya juga merasa perlu untuk berlaku sebagai pihak berwenang dan menertibkan perilaku mereka. 
Ruswandhi juga sempat "menertibkan" Luna dan Ariel. Mereka, katanya, "ditangkap" komandan regu keamanan kompleks. "Ia pernah datang bersama Ariel dini hari. Saya punya danru yang seorang tentara pernah menahan KTP Ariel sama Luna Maya..Ariel sering menginap di sini," ungkapnya (Ibid, 4).

Tindakan Ariel dan Luna yang tidur di bawah satu atap, yang walaupun dilakukan tepat di atas properti pribadi, namun masih dalam teritori kekuasaan rumah "Bapak" yang oleh negara diwakilkan pada Ketua RT, dianggap menyalahi identitas bangsa yang menempatkan hal tersebut sebagai melanggar norma moral. Sehingga Pak RT merasa perlu memanggil komandan regu keamanan, yang seorang tentara, untuk "menangkap" keduanya dan kemudian menahan KTP Ariel.

Menkominfo, sebagai perwakilan dari Presiden, yang diserahi tanggung jawab pada peredaran informasi di rumah "keluarga besar Indonesia" pun merasa perlu memberikan pengarahan kepada para pelaku, penonton sekaligus pengedar informasi ini.

Padahal, tekanan dari berbagai kalangan agar masalah ini segera dituntaskan semakin kuat saja. Bahkan Presiden SBY pun akhirnya ikut bersuara mengenai kasus ini. Intinya, SBY mendukung pemeriksaan hingga tuntas, antara lain demi menjaga moral bangsa ini (Tabloid Nova, No.1165, 2010: 3).

Kalau bisa ada lembaga yang memberikan award untuk Ariel sebagai orang yang berhasil merusak generasi bangsa sepanjang sejarah Masalah video itu cukup menguras perhatian publik. Kalau itu benar mereka, bukan saya saja yang kecewa. Mereka ini idola puluhan juta jiwa anak muda Indonesia. Dan ini bisa menjadi preseden buruk (Tabloid Bintang, Edisi 997, 2010:4).

Menkominfo TifatulSembiring meminta Ariel, Luna Maya, dan Cut Tari membantu kepolisian dengan mengaku terus terang, "Saya imbau supaya mereka bersikap gentle. Videonya ada dan tersebar luas, tapi tidak ada yang mengaku bertanggung jawab" (Tabloid Genie, Edisi 50, 2010: 5).

Imbauan" diberikan oleh menkominfo sebagai perwakilan dari "Bapak Negara" ke- pada para anak bangsa yang melakukan illegitimate sexual activity untuk mempertanggungjawabkan perbuatannya. Bentuk tanggung jawab macam apa yang dituntut tidak dijelaskan secara eksplisit, namun "Bapak" Menteri menghimbau mereka untuk setidaknya mengaku dan memohon maaf kepada Bangsa Indonesia. Utamanya kepada adik-adik mereka yang menjadikan para selebritis ini sebagai "role model". Preseden yang disampaikan oleh Tifatul bisa jadi mengarah pada perusakan identitas nasional yang sudah dikonstruk bertahun-tahun mengenai illegitimate sexual activity.

Untuk itulah, militer, yang dalam hal ini diwakili oleh pihak kepolisian menjadi alat negara dalam menegakkan moral bangsa. Dengan kata lain, illegitimate sexual activity, menurut "Bapak" adalah tindakan perusakan moral bangsa, sehingga untuk menggesernya ke tepi diskursus seksualitas diperlukan repressive state apparatus, yang dalam hal ini adalah polisi.

Dari semua artikel yang dimuat oleh tabloid-tabloid tersebut, negara diposisikan sebagai institusi puncak yang memiliki legitimasi dalam mendefinisikan posisi tiap pemain dalam kerangka narasi ini. Nagara pula yang dianggap sebagai sutradara yang harus bertanggungjawab atas "kenakalan" para pemainnya untuk kemudian ditindak sesuai dengan diskursus seksualitas yang telah direproduksinya terus-menerus. Hal ini memperkuat diskursus heteronormativitas yang dianut oleh Indonesia. Seperti yang disampaikan oleh Rubin (1984: 14).

...Sexuality that is "good", "normal" and "natural" should ideally be heterosexual, marital monogamous, reproductive and non-commercial. It should be coupled, relational, within the same generation and occur at home. It should not involve pornography, fetish objects, sex toys of any short, or roles other than male and female. Any sex that validates this rules is "bad, "abnormal", or "unnatural". Bad sex may be homosexual unmarried, promiscuous, non-procreative, or commercial. It may be masturbatory or take place at orgies, may be causal, may cross generational lines, and may take in "public", or at least in the bushes or the baths. It may involve the use of pornography, fetish objects or unusual roles. 
Maka setiap aktivitas seksual yang berada di luar ranah good sexuality harus "diluruskan" oleh institusi puncak yang memiliki legitimasi dalam menata diskursus seksualitas, yang dalam konteks heteronormativitas adalah maskulin. Dengan kata lain, jika ditarik lebih jauh lagi dalam tataran Indonesia, simbol maskulinitas dalam asas kekeluargaan bangsa terletak pada Presiden dan aparaturnya sebagai "Bapak" bangsa yang memiliki legitimasi pendefinisian seksualitas yang "patut", menggunakan kerangka nasional maskulin, bukannya multikultural.

\section{SIMPULAN}

Berdasarkan pembahasan tersebut, saya dapat mengambil kesimpulan bahwa diskursus illegitimate sexual activity yang didokumentasikan, masih menjadi realitas yang secara kultural bisa diperdebatkan bagi tabloid Indonesia. Melihat dari perspektif multikulturalisme kritis, tabloid Indonesia masih berada pada posisi hegemoni ideologi dominan negara yang menganut heteronormativitas. Pendefinisian fenomena tersebut diambil dari sudut pandang negara yang meletakkan diskursus seksualitas di peripheri wacana kebangsaan. Sehingga illegitimate sexual activity yang didokumentasikan tersebut dijadikan indikator moralitas bangsa sekaligus, sebuah aib yang harus direpresi secara hukum publik karena mengakibatkan "kerusakan" moral bangsa.

Terkait dengan konstruksi identitas nasional yang direproduksi terus-menerus melalui wacana kebangsaan menggunakan sistem penandaan, media massa sebagai agen dari sistem penandaan negara menjalinkan diskursus seksualitas tanpa legitimasi tersebut sebagai pelanggaran yang sudah selayaknya diberikan hukuman. Media massa sebagai ideological state apparatus memainkan perannya dalam mengkonstruksi pandangan publik mengenai peristiwa tersebut sejalan dengan wacana kebangsaan. Para narasumber yang digunakan oleh tabloid untuk mengulas permasalahan ini juga didasarkan pada legitimasi negara melalui kredibilitas narasumber tersebut.
Setiap tabloid yang membahas kasus tersebut, belum mampu memperluas pandangan mereka di luar diskursus tersebut sehingga pemberitaan yang dipublikasikan cenderung seragam. Namun, tidak bisa dikatakan mutlak demikian, karena tabloid Indonesia mulai berani menampilkan suarasuara marginal yang dalam hal ini diwakili oleh para pemeran video tersebut. Sangat disayangkan, ketika masyarakat sebagai pihak yang bersinggungan langsung dengan dampak yang ditimbulkan dari peristiwa tersebut tidak mendapatkan tempat untuk berbicara. Yang terakhir, menurut saya pemberitaan dari para tabloid tersebut menjadi berlebihan mengingat pengulangan dan peletakkannya sebagai isu utama, karena hal ini berimplikasi pada konstruksi isu yang dianggap penting bagi publik, sehingga masyarakat melupakan isu-isu lainnya.

\section{DAFTAR PUSTAKA}

Alimi, Yasir. M., 2004, Dekonstruksi Seksualitas Poskolonial: Dari Wacana Bangsa Hingga Wacana Agama, Jogjakarta: LKiS.

Anderson, B., 1983, Imagined Communities: Reflection on the Origin and Spread of Nationalism, London: Verso.

Butler, J., 1999, "Gender Trouble" da-lam Feminism and The Subversion of Identity, London: Routledge.

Fiske, J., 1996, “Communication, Meaning and Sign" dalam Introduction to Communication Studies, London: Routledge.

Foucault, M., 1968, "Discourse, Power and Knowledge", dalam The Will to Truth, New York: Tavistock Publication.

Hall, S., 2002, "The Work of Representation" dalam Stuart Hall (ed.), Representation; Cultural Representations and Signifying Practices, London: Sage Publication.

Ibrahim, Subandy. I., 2007, Budaya Populer sebagai Komunikasi: Dinamika Popscape dan Mediascape di Indonesia Kontemporer, Bandung: Jalasutra. 
Kellner, D., 1995, Media Culture, New York: Routledge.

Littlejohn, S. W., 2000, "Critical Theories" dalam Theories of Human Communication. London: Wasdworth Publishing. , 2000, Theories of Human Communication, London: Wasdworth Publishing.

McLaughlin, L., 2000, The Language of Magazines, New York: Routledge.

McQuail, D., 2000, "Theory of Media and Theory of Society" dalam Mass Communication Theories, London: Sage Publication.

Rubin, G., 1984, " Thinking Sex: Notes for a Radical Theory of the Politics of Sexuality". Boston and London: Routledge.

Rubin, G., 1984, Thinking Sex: Notes for a Radical Theory of the Politics of
Sexuali-ty, Boston and London: Routledge.

Suryakusuma, J. I, 1991, “Seksualitas dalam Pengaturan Negara" dalam Liza Hadiz (ed.), Perempuan dalam Wacana Politik Orde Baru: Pilihan Artikel Prisma, Jakarta: LP3S.

Tabloid Bintang Edisi 997 Tahun XX, Minggu Kedua Juni 2010.

Tabloid Genie Edisi 50 Tahun VI, 21-27 Juni 2010.

Tabloid Nova No. 1165/XXIII 21-27 Juni 2010.

Tabloid Wanita Indonesia No. 1069 21-27 Juni 2010 